\title{
BRAND ACTIVATION, STRATEGI KOMUNIKASI PADA LEMBAGA SURVEI POLITIK DI PUTARAN PERTAMA PILKADA DKI JAKARTA 2017
}

\author{
Diah Ayu Candraningrum \\ Fakultas Ilmu Komunikasi, Universitas Tarumanagara \\ diahc@fikom.untar.ac.id
}

\begin{abstract}
ABSTRAK
Paska era reformasi 1998 di Indonesia, lembaga survei politik menjamur. Ajang pemilihan kepala daerah dan presiden menjadi arena pembuktian eksistensi mereka. Jumlahnya pun semakin bertambah setiap tahun. Mereka seakan berebut menjadi yang pertama, yang mampu memprediksi pemenang pilkada dan pilpres, sebelum Komisi Pemilihan Umum merilis pengumuman resminya. Untuk menghasilkan prediksi yang mendekati presisi atas kemenangan pasangan calon pemimpin, tidak mudah caranya. Prosedur kerja lembaga survei sangat ketat dan detil. Perputaran uang yang beredar dalam setiap kegiatan itu pun tak sedikit. Mereka juga melakukan pendekatan strategi komunikasi pemasaran politik kepada khalayak. Dengan landasan brand activation, yang merupakan pendekatan baru dalam aktivitas komunikasi pemasaran politik, penulis mengajak masyarakat untuk memahami merek lembaga survei politik secara lebih baik. Dengan menggunakan metode penelitian kualitatif deskriptif lewat studi kasus Pemilihan Gubernur dan Wakil Gubernur (Pilkada) DKI Jakarta 2017, penulis mendapatkan gambaran bahwa pemenang perang hasil hitung cepat atau quick count, adalah lembaga yang pemimpin atau penelitinya dianggap kredibel dan independen, sebagai penajmin mutu. Penulis berupaya supaya tulisan ini bisa menjadi kajian yang menarik bagi pendidikan berpolitik di Indonesia.
\end{abstract}

Kata kunci: lembaga survei politik, pilkada, quick count, brand activation, brand trust

\section{PENDAHULUAN}

\section{Bisnis Hitung Cepat}

Setiap momen pemilihan presiden atau pemilihan kepala daerah, tak hanya membuat penasaran siapa yang akan terpilih. Namun juga menyisakan satu hal yang banyak disebut-sebut setelah kegiatan pencoblosan digelar, yakni hitung cepat alias quick count.

Menurut Kamus Besar Bahasa Indonesia, hitung cepat berasal dari kata "hitung" yang berarti yang berarti "proses menghitung" serta "cepat" yang berarti "dengan segera". Secara singkat, hitung cepat didefinisikan sebagai metode untuk mengetahui hasil pemilihan umum dengan melakukan verifikasi melalui sampel hasil pemilu di Tempat Pemungutan Suara atau TPS.

Banyak lembaga survei politik, maupun bagian penelitian dan pengembangan (Litbang) perusahaan media, yang menggelar perolehan suara masing-masing pasangan calon lewat berbagai metode pengambilan sample, dengan tingkat margin error tertentu.

Hal ini tampak dalam ajang Pemilihan Kepala Daerah DKI Jakarta putaran pertama yang digelar 15 Februari 2017 lalu. Berdasarkan laman resmi KPU DKI Jakarta, www.kpujakarta.go.id, ada 32 lembaga survei yang mendaftar. Sebagian besar merupakan nama-nama yang sering terdengar, namun beberapa di antaranya, pemain baru. Keberadaan lembaga survei memang diatur dalam Peraturan KPU Nomor 5 Tahun 2015 tentang Peran Lembaga Survei untuk Pendidikan Politik.

Menariknya bisnis ini, karena perputaran uang yang nilainya fantastis. Pada Pilpres 2014 lalu, beberapa lembaga survei telah diaudit oleh Perhimpunan Survei Opini Publik Indonesia (Persepsi), di antaranya besaran biaya. 
Menurut Anggota Dewan Etik Persepi Hamdi Muluk, jumlah biaya yang digunakan oleh sejumlah lembaga survei untuk menggelar quick count 2014 sangat bervariasi, tergantung jumlah sample yang digunakan. Kisarannya dari Rp 1,3 miliar hingga Rp 20 miliar. Dananya, berasal dari perusahaan media dimana lembaga survei itu menjadi partner.

Martabat organisasi pun bisa terangkat saat hasil hitung cepat dan analisanya terbukti saat pengumuman resmi KPU. Artinya, lembaga tersebut menjadi kredibel dan independen, karena dianggap tidak menerima survei pesanan atau melakukan survei abal-abal.

Quick count sendiri dapat memperkirakan perolehan suara pemilu secara cepat sehingga dapat memverifikasi hasil resmi KPU. Lebih jauh, hitung cepat mampu mendeteksi dan melaporkan penyimpangan, atau mengungkap kecurangan.

Namun untuk mendapat hasil tersebut, banyak sekali tahapan yang harus dilalui sebelum mendapatkan hasil quick count yang minim kesalahan. Pertama, menentukan sampel TPS secara acak. Semakin besar sample yang diambil, tingkat akurasinya semakin tinggi.

Kedua, mencari relawan yang akan bertugas memantau TPS hingga rekapitulasi suara, kemudian mengirimkan ke pusat data. Inilah komponen terbesar dalam penyelenggaraan quick count, yakni pembayaran honor relawan.

Ketiga, simulasi quick count. Cara ini dilakukan sekaligus sebagai uji coba menggunakan mesin hitung cepat yang telah dipersiapkan, apakah bekerja dengan baik atau tidak. Keempat, pengiriman rekapitulasi suara ke pusat data. Setelah data masuk, kemudian ditabulasi di data center. Terakhir, mengolah data dan menampilkan hasil akhir, dengan menggunakan perangkat lunak yang canggih.

Berdasarkan penjelasan di atas, tujuan dari penulisan makalah ini adalah untuk mendapatkan gambaran tentang strategi komunikasi pemasaran politik seperti apa yang dilakukan oleh beberapa lembaga survei politik, yang berhubungan dengan aktivitas brand activation untuk menumbuhkan brand trust di kalangan masyarakat. Objek penelitian ini terbatas pada lembaga survei politik yang selama ini namanya kerap muncul di media, menjelang Pilkada DKI Jakarta 2017.

\section{Strategi Komunikasi Politik}

Strategi komunikasi politik biasanya terkait erat dengan retorika dan propaganda (Romarheim, 2005). Dua varian penting dalam komunikasi ini memang terbukti sangat sulit dipisahkan. Menurut Jowett \& O'Donnell (1999:6) dan Ellul (1973) dalam Romarheim (2005), yang disebut propaganda adalah strategi komunikasi massa yang dilakukan organisasi untuk membentuk persepsi dan memanipulasi masyarakat. Sedangkan retorika adalah hal-hal yang digunakan sebagai alat untuk mempersuasi, dimana persuasi tersebut akan menghasilkan proses komunikasi yang interaktif.

Saat sebuah pernyataan mengandung konotasi dan asosiasi negatif, kalimat pelembut pun segera bermunculan. Karena itu, penggunaan strategi propaganda akan menggerakkan dukungan publik terhadap satu isu.

Untuk pemahaman yang lebih baik mengenai politik di masyarakat, diperlukan pemahaman komunikasi dalam berbagai bentuk. Salah satunya, model komunikasi Aristoteles (Romarheim, 2005):

$$
\text { Pembicara }--\rightarrow \text { Argumentasi }--\rightarrow \text { Pidato }--\rightarrow \text { Audiens }
$$


Bentuk komunikasi di atas dapat diartikan sebagai bentuk penyebarluasan argumentasi yang diyakini satu pihak dan berusaha untuk disebarluaskan. Upaya komunikasi inilah yang akan dinilai oleh masyarakat, yang pada akhirnya akan menghasilkan kepercayaan masyarakat. Jika kepercayaan telah diraih, maka hubungan antara pihak tersebut dan masyarakat, telah terjalin dengan baik.

\section{Brand Activation}

Brand activation adalah interaksi dua arah antara konsumen dan brand itu sendiri yang menghasilkan hubungan yang erat antara keduanya (Saeed, 2015). Lewat aktivasi merek ini, konsumen mendapatkan pengetahuan mendalam tentang merek dan menerima sebagai bagian dari dirinya.

Brand activation ini bisa dianggap sebagai stimulus positif bagi konsumen untuk mulai menghargai merek tersebut. Selanjutnya, konsumen dibawa untuk mengetahui bahwa proses pengaktifan merek ini dilakukan secara menyeluruh hingga menyentuh sisi emosional konsumen. Setelah konsumen percaya dan yakin pada brand tersebut, merupakan indikator bahwa brand tersebut memiliki kualitas baik atau memiliki kekuatan merek yang tangguh di pasar. (Keller, 2013)

Aktivasi di sini bisa diartikan sebagai proses membangun ketertarikan, proses mencoba hingga akhirnya membangun kesetiaan. Aspek awal dari aktivasi adalah membangun ketertarikan, artinya bisa dilakukan lewat fokus pada target pasar mana yang akan dituju, khususnya pada pelanggan baru.

Aspek kedua adalah menghadapi langsung. Setelah mampu membuat konsumen tertarik, fokus selanjutnya adalah membuat percobaan bagi calon konsumen tadi, yang tentunya berusaha meninggalkan kesan positif. Sedangkan aspek terakhir adalah menciptakan kesetiaan pelanggan. Inilah tujuan utama dari kegiatan brand activation. Karena kesetiaan akan membawa pada pengggunaan produk lagi dan lagi. Selain itu, hal ini menunjukkan kedekatan antara brand dengan konsumennya.

Berbeda dengan iklan. Kegiatan branding lebih dari sekedar beriklan. Iklan hanya sebatas memberikan janji, sedangkan aktivasi adalah bagaimana merealisasikan janji-janji ini. Jika manfaat iklan adalah untuk menginformasikan kepada konsumen, kegiatan brand activation adalah membangun kepercayaan antara pelanggan dan perusahaan.

Brand activation sendiri dapat dikatakan sebagai sebuah proses untuk menciptakan pengalaman dengan brand. Pengalaman ini sendiri terdiri atas pemikiran, perasaan, sensitivitas, seni dan hubungan dengan brand itu sendiri (Hussain, 2013 dalam Saeed, 2015).

\section{Brand Trust}

Tujuan akhir dari kegiatan pemasaran adalah menciptakan ikatan yang kuat antara konsumen dengan merek. Kunci utama untuk mendapatkan ikatan tadi adalah kepercayaan (Hiscock dalam Ballister, 2003). Dengan kepercayaan yang kuat, konsumen tak ragu dalam memilih merek karena mereka merasa puas. Dengan kepuasan tersebut, mereka akan menjadi konsumen yang loyal. 
Hal yang sama juga dikatakan O'Shaughnessy (1992) dalam Lau and Lee (1999:342) bahwa dasar dari kesetiaan pelanggan adalah kepercayaan, yakni keputusan yang diambil tanpa memikirkan biaya maupun manfaat. Salah satu cara membangun kepercayaan adalah dengan cara membangun hubungan individual yang baik serta menjalin hubungan interpersonal yang baik antara individu dengan merek sebagai simbol.

Merek telah menjadi pembawa nilai emosional terhadap pelanggan dan simbol tertentu serta kompetensi yang membangun keunggulan kompetitif perusahaan.

\section{METODE PENELITIAN}

Setelah mengetahui definisi dan penjelasan sebelumnya, peneliti memutuskan untuk menggunakan metode penelitian kualitatif yang bersifat deskriptif. Menurut pendapat John W. Cresswell, 2003:1, penelitian kualitatif didefinisikan sebagai sebuah proses penyelidikan, untuk memahami masalah sosial atau masalah manusia. Pemahaman ini didasarkan pada penciptaan gambar secara holistik dan lengkap, yang dibentuk dengan kata-kata, melaporkan pandangan secara terperinci dan disusun dalam sebuah latar alamiah.

Sedangkan pengertian jenis penelitian deskriptif sendiri adalah jenis penelitian yang bertujuan untuk menggambarkan fenomena-fenomena yang ada, baik fenomena alamiah maupun fenomena buatan manusia. Fenomena itu sendiri bisa berupa bentuk, aktivitas, karakteristik, perubahan, hubungan, kesamaan dan perbedaan antara fenomena yang satu dengan lainnya.

Penelitian deskriptif ini pada umumnya, dilakukan dengan tujuan utama yaitu menggambarkan secara sistematis antara fakta, karakteristik obyek dan subyek yang diteliti secara tepat.

Sebagai kajian ilmiah, teknik pengumpulan data dilakukan melalui studi pustaka dengan mencermati beberapa referensi dan artikel-artikel terkait dengan tema kajian dari beberapa situs di internet.

\section{HASIL DAN PEMBAHASAN}

Di ajang Pilgub DKI Jakarta 2017 yang digelar 15 Februari lalu, tepat pada pukul 13.00 WIB, banyak lembaga survei yang mengumumkan hasil hitung cepat versinya masing-masing. Ada lembaga survei yang menjadi partner perusahaan media. Sebagai partner media televisi, peneliti atau pemimpin lembaga survei tersebut duduk sebagai narasumber utama saat program acara hitung cepat berlangsung.

Contohnya Burhanuddin Muhtadi dari Indikator Politik Indonesia dengan Eep Syaifulloh dari Polmark Indonesia sebagai narasumber utama di stasiun tv TVONE. Sedangkan Yunarto Wijaya dari Charta Politica dan Moh. Qodari dari Indo Barometer, sama-sama menjadi narasumber utama di stasiun tv Metro TV. Mereka tak hanya menjadi analis, namun juga mempresentasikan capaian hitung cepat yang dilakukan organisasinya, untuk dinikmati masyarakat secara real time.

Sebagai partner media online, Lingkaran Survei Indonesia menggandeng portal berita detik.com. Sedangkan Kelompok Diskusi dan Kajian Opini Publik Indonesia (Kedai Kopi) digandeng portal berita ekonomi Katadata.com. Berbeda dengan media lain, stasiun tv Kompas TV mempercayakan hasil hitung cepatnya pada bagian penelitan dan pengembangan (Litbang) Kompas, yang masih dalam induk perusahaan yang sama.

Di akhir masa penghitungan quick count, semua lembaga survei sama-sama memberikan hasil hitungan cepat versinya. Adanya perbedaan hasil, sangat dipengaruhi oleh metodologi, teknik 
pengumpulan data yang digunakan serta kemungkinan kedekatan antara lembaga survei dengan partai politik tertentu.

Namun dari kerjasama tadi, tampak jelas bahwa masing-masing lembaga survei telah melakukan brand activation, sehingga dilirik perusahaan media untuk menjadi rekanannya. Perusahaan media telah melalui seleksi yang cukup ketat untuk menentukan lembaga survei mana yang akan digandeng pada hari pencoblosan.

Memang, belum ada pernyataan resmi dari masing-masing perusahaan media, mengenai alasan di balik pemilihan rekan untuk penayangan hasil hitung cepatnya secara real time. Namun jika dikaitkan dengan brand activation yang akan menumbuhkan brand trust, yang telah dilakukan oleh masing-masing lembaga survei sebelumnya, hal ini akan menunjukkan mengapa mereka yang dipilih.

Pada 2-8 Februari 2017, Indikator Politik Indonesia melakukan survei elektabilitas pasangan calon gubernur dan wakil guernur DKI Jakarta. Hasil jajak pendapat menyatakan pasangan Basuki Tjahaja Purnama-Djarot Syaiful Hidayat menempati urutan teratas yakni 39,04\%, berkat dua debat publik yang digelar sebelumnya.

Hasil jajak pendapat ini jauh berbeda dengan hasil survei elektabilitas pasangan calon yang dilakukan oleh lembaga survei Polmark Indonesia. Survei yang digelar pada 6-12 Januari 2017 ini menghasilkan elektabilitas pasangan Anies Baswedan-Sandiaga Uno menduduki posisi tertinggi yakni $25,3 \%$.

Pada 3-8 Februari 2017, lembaga survei Charta Politica juga menggelar survei elektabilitas pasangan calon gubernur dan wakil gubernur DKI Jakarta. Hasilnya, jika pilkada digelar hari itu, pasangan calon Basuki Tjahaja Purnama-Djarot Syaiful Hidayat yang akan menang dengan perolehan suara sebesar 39\%.

Lain lagi dengan Indo Barometer yang tak melaksanakan jajak pendapat jelang Pilkada DKI digelar. Lembaga ini hanya melaksanakan survei pada Juli 2016, untuk mengetahui nama-nama yang memiliki elektabilitas tinggi. Posisi pertama diraih oleh Basuki Tjahaja Purnama dengan $35 \%$.

Sedangkan survei elektabilitas Kedai Kopi yang dilakukan pada 19-24 October 2017 menyebut, pasangan Basuki-Djarot meraih suara terbanyak, yakni 27,5\%. Senada dengan hasil survei jajak pendapat yang dilakukan Litbang Kompas pada 28 Januari-4 Februari 2017, dimana elektabilitas pasangan Basuki-Djarot meraih 36,2\%

Namun berbeda dengan survei yang dilakukan Lingkaran Survei Indonesia, yang digelar pada 511 Januari 2017. Hasilnya, pasangan Agus Harimurti Yudhoyono-Slyviana Murni menduduki posisi teratas sebesar $36,7 \%$.

Dari hasil jajak pendapat di atas, terlihat benar bagaimana proses brand activation yang dilakukan oleh masing-masing lembaga survei. Sebelum hari pemilihan berlangsung, jauh hari masing-masing lembaga survei tersebut telah berusaha mengaktifkan mereknya, dengan mengeluarkan hasil jajak pendapat mengenai siapa pasangan calon yang memiliki tingkat keterpilihan tertinggi.

Bahkan Indikator Politik Indonesia intens menggelar jajak pendapat pada bulan Januari dan Februari, sebelum hari pencoblosan. Tidak hanya itu, Direktur Eksekutif Indikator Politik Indonesia Burhanuddin Muhtadi, juga sering muncul di media untuk menjelaskan analisanya. 
Dalam penjelasan hasil quick count pada ajang pemilihan presiden dan wakil presiden tahun 2014 pun, Burhanuddin mengaku mendapatkan dana dari Metro TV. Meski dia mengklaim pihaknya tak mendapat pesanan untuk memenangkan calon presiden tertentu.

Apa yang dia lakukan merupakan langkah brand activation yang sesungguhnya. Ulasan dan penampilannya di berbagai media, merupakan stimulus positif untuk mengenalkan merek lembaganya yang baru berdiri tahun 2013 ini. Inilah kesempatan bagi pihaknya, untuk menyebarluaskan propaganda yang diyakini organisasinya telah melalui jalur yang benar, sebagai bagian dari strategi komunikasi politik.

Independensi lembaga survei ini juga patut diperhitungkan, karena sampai hari ini tidak terbukti adanya kedekatan relasi dengan partai politik manapun. Dengan pembiayaan survei dari pihak kedua (Metro TV), yang kemudian menayangkannya secara live, menunjukkan adanya kepercayaan kepada merek tersebut (brand trust).

Untuk mendukung kepercayaan terhadap merek yang dimilikinya, Burhanuddin juga melakukan survei lain yang tak terkait dengan pemilihan umum, namun terkait dengan independensi dan kepercayaan masyarakat. Pada Agustus 2016, Indikator mengeluarkan hasil survei tentang lembaga negara yang paling dipercaya, yaitu Presiden, TNI dan Komisi Pemberantasan Korupsi (KPK).

Hal yang sama juga diterapkan oleh lembaga survei baru Kedai Kopi. Sebagai lembaga survei yang relatif baru berdiri, merupakan prestasi tersendiri bisa menyelenggarakan sebuah proses hitung cepat, yang berpartner dengan salah satu media online. Sepak-terjang dan independensi pendirinya Hendri Satrio, yang aktif menjadi narasumber pengamat politik di media, bisa menjadi salah satu acuan khalayak untuk mendengarkan dan memperhatikan hasil quick count. Brand activation telah mulai dibangun dan sebagai hasil nyata. Hasilnya, brand trust pun terwujud.

Sebagai lembaga survei baru, Kedai Kopi sangat menyadari hal itu dan berusaha melakukan strategi untuk menanamkan brand awareness mereknya di masyarakat. Caranya lewat berbagai jajak pendapat yang mereka lakukan, yang secara tidak langsung berkontribusi pada aspirasi politik masyarakat. Salah satu jajak pendapat yang mereka lakukan adalah mengukur elektabilitas Gubernur DKI Jakarta Basuki Tjahaja Purnama pada Oktober 2016. Hasilnya, elektabilitas gubernur incumbent ini dinilai turun menjadi 27,5\% dari bulan September 2016 sebesar 39\%. Media pun mengutipnya dan masyarakat pun mengenal merek ini.

Direktur Eksekutif Charta Politika Yunarto Wijaya dan Direktur Eksekutif Indo Barometer Muhammad Qodari sendiri juga merupakan nama-nama yang popular sebagai pengamat politik di media. Pernyataan mereka banyak dikutip media. Mereka juga banyak tampil di stasiun televisi.

Organisasi yang mereka pimpin pun kerap menyelenggarakan survei atau jajak pendapat, sehingga nama mereka tetap tertanam dalam brand awareness masyarakat. Beberapa kali hasil survei lembaga mereka dipertanyakan keabsahannya. Hal ini tentu saja merupakan salah cara pengaktifasian merek, meski dengan cara yang kurang menyenangkan.

Strategi brand activation lain yang digunakan Lingkaran Survei Indonesia (LSI) pimpinan Denny JA adalah, mengeluarkan hasil survei yang memberikan hasil berbeda dengan lembaga survei lain, yang juga kebetulan merupakan pecahan kongsi sekaligus memiliki nama yang hampir sama. Survei yang dilakukan Lingkaran Survei Indonesia dan Lembaga Survei Indonesia, dilakukan dalam kurun waktu yang berdekatan namun hasilnya berbeda. 
LSI pimpinan Denny JA menggelar survei yang melibatkan 880 responden pada 1-6 Desember 2016. Hasilnya, pasangan calon gubernur dan wakil gubernur DKI Jakarta Agus-Sylvi memperoleh dukungan tertinggi dari masyarakat, yakni 33,6\%. Sedangkan LSI pimpinan Kuskridho Ambardi menggelar survei pada 3-11 Desember 2016 dengan 800 responden. Hasil akhirnya menunjukkan, tingkat keterpilihan Ahok-Djarot sebesar 31,8\%, tertinggi di antara pasangan calon lainnya.

Meski telah berdiri sejak 2003, LSI Denny JA tampaknya masih perlu melakukan strategi brand activation karena citra mereknya sempat menurun setelah dikaitkan dekat dengan partai politik tertentu. Sebab, LSI pimpinannya kini telah mengembangkan bisnis menjadi konsultan politik sehingga masyarakat pun mempertanyakan keabsahan hasil jajak pendapatnya. Yang jelas, dua LSI yang berbeda hasil ini kian menyemarakkan hitung-hitungan menuju kursi DKI-1.

Khusus untuk Litbang Kompas, sejak lama memang telah dikenal sebagai unit bisnis untuk riset kepentingan pemberitaan Grup Kompas Gramedia. Namun belakangan, Litbang Kompas dikembangkan untuk berbagai keperluan penelitian, yang disesuaikan dengan fenomena yang terjadi di masyarakat. Sejauh ini, kegiatan Litbang Kompas belum diatur secara komersial. Artinya, kinerja unit bisnis penelitian yang menyandang nama Kompas ini dikenal dengan kredibilitasnya sebagai lembaga penelitian yang independen.

\section{KESIMPULAN DAN SARAN}

Kegiatan aktivasi merek adalah langkah yang efektif dalam rangka menumbuhkan kepercayaan pada masyarakat. Di tengah kepungan aneka merek di sekitarnya, konsumen yang cerdas pasti akan memilih yang terbaik menurut dia, berdasarkan proses aktivasi merek (brand activation) yang dilakukan oleh brand tersebut. Adalah tanggung jawab pengelola brand, untuk membuat konsumennya percaya dan yakin akan kualitas brand tersebut (brand trust).

Dalam kaitan dengan fenomena menjamurnya lembaga survei di Indonesia, banyak aspek yang perlu diperhatikan dalam membangun merek dan membangun kepercayaan publik. Jaminan mutu dan kualitas survei yang dihasilkan, amat sangat tergantung pada popularitas nama pendiri atau nama peneliti, yang identik dengan lembaga tersebut.

Kredibilitas peneliti juga dilihat dari kepopuleran namanya di media, apakah terkait dengan tokoh politik tertentu atau tidak. Juga apakah lembaga survei tersebut menjalankan fungsi konsultan politik atau tidak. Karena itu, sangatlah penting bagi pengelola lembaga survei untuk tetap mempertahankan independensi diri dan lembaganya, supaya menghasilkan brand activation dan brand trust yang kuat di masyarakat.

Berbisnis survei sama artinya dengan bisnis media. Kepercayaan adalah yang utama. Bagaimana mengelola uang dalam jumlah besar, dan bagaimana menjaga independensi organisasi agar tetap bercitra positif di mata publik. Menjaga dan mempertahankan citra brand yang telah populer di masyarakat sangatlah sulit. Apalagi bagi sebuah brand yang baru muncul. Adalah tantangan besar menanti di depan mata, untuk bisa diposisikan sejajar dengan existing brand, apalagi mengalahkannya.

Brand activation akan sangat memegang peranan dalam mempopulerkan brand tersebut. Kegiatan komunikasi pemasaran yang dilakukan lembaga survei, dipercaya mampu mendongkrak kesadaran masyarakat (brand awareness) terhadap popularitas lembaga tersebut. 
Bagi para pemilik maupun pengelola lembaga survei, adalah tanggung jawab besar untuk menjadikan lembaga ini sebagai pendukung kekokohan sistem demokrasi di Indonesia. Karena jajak pendapat dan hitung cepat, merupakan bukti betapa pentingnya memahami aspirasi publik, yang bisa menjadi masukan bagi kehidupan demokrasi yang lebih baik.

\section{ACKNOWLEDGEMENT}

Dalam menyusun makalah ini, penulis banyak mendapatkan inspirasi dari berbagai pihak. Pun, tak sedikit pihak-pihak yang membantu penulis sehingga akhirnya dapat terselenggara penelitian ini. Meski tak bisa disebutkan satu persatu, ijinkan penulis mengucapkan terimakasih kepada:

- Tuhan YME, karena hanya karena karuniaNya-lah penelitian ini dapat terwujud.

- Rektor Universitas Tarumanagara, Bp. Prof. Dr. Agustinus Purna Irawan, beserta jajaran pemimpin universitas, yang telah memberi kesempatan untuk berpartisipasi dalam kegiatan Seminar Nasional.

- Dekan Fakultas Ilmu Komunikasi Universitas Tarumanagara, Ibu Dr. Riris Loisa, MSi beserta jajaran pemimpin fakultas, yang tak kenal lelah menyemangati penulis.

- Rekan-rekan sesama Dosen dan karyawan di lingkungan Fikom Untar, yang tak dapat penulis ucapkan satu persatu. Terimakasih atas pertemanan, kerjasama dan dukungannya.

\section{REFERENSI}

Ballister, Degalgo Elena (2003). Development and Validation of a Brand Trust Scale. International Journal of Market Research. (http://citeseerx.ist.psu.edu/viewdoc/download?doi=10.1.1.201.5789\&rep=rep1\&type=p df), diakses pada 25 Februari 2017

Creswell, John. W (2014). Research Design: Qualitative, Quantitative and Mixed Methods Approaches $4^{\text {th }}$ Edition. California: Sage Publications Inc.

Keller, Kevin Lane, (2013). Strategic Brand Management. Building, Measuring and Managing Brand Equity. Fourth Edition. Essex: Pearson.

Kotler, Philip and Keller, Kevin Lane (2012). Marketing Management. Fourteenth Edition. New Jersey: Prentice Hall.

Lau, Geok Theng; Sook Han Lee (1999). Consumer's Trust in a Brand and the Link to Brand Loyalty. Journal of Market-Focused Management; December 1999; 4,4; ABI/INFORM; pg $341 \quad$ (http://cmaps.cmappers.net/rid=1K0GXW9DN-24VWNVBMQJ/Lau\%26Lee\%20(1999).pdf), diakses pada 26 Februari 2017

Pribadi, Muhammad Adi, MIB, MComm, (2013). "Strategi Penggunaan Facebook Sebagai Alat Komunikasi Pemasaran Hotel”. Konferensi Nasional Ilmu Komunikasi, Bali, 16 April 2013, 401 .

Romarheim, Anders G (2005). Definitions of Political Strategies Communication; no. 689, 2005. Norwegian Institute of International Affair (https://www.files.ethz.ch/isn/27824/689.pdf), diakses pada 12 Maret 2017

Saeed, Rashid; Zameer, Hashim; Tufail, Sajid; Ahmad, Iftikhar (2015). Brand Activation: A Theoretical Perspective. Journal of Marketing and Consumer Research. ISSN 2422-8451 
BRAND ACTIVATION,

STRATEGI KOMUNIKASI PADA LEMBAGA SURVEI

POLITIK DI PUTARAN PERTAMA PILKADA DKI

JAKARTA 2017

Vol.

13 , 2015

(http://www.iiste.org/Journals/index.php/JMCR/article/viewFile/24494/25069), diakses pada 25 Februari 2017

Tamburian, H.H Daniel, S.Sos, M.Si, (2013). "Aktivitas Marketing Komunikasi Hotel Amaris Dalam Memenangkan Persaingan di Segmen Hotel Budget". Konferensi Nasional Ilmu Komunikasi, Bali, 16 April 2013, 393.

Widyastuti, Dhyah Ayu Retno, (2013). "Brand Activation, Pergeseran Pendekatan Strategi Komunikasi Pemasaran. Studi pada GMF AeroAsia dalam Membangun Kepercayaan Merek”. Konferensi Nasional Ilmu Komunikasi, Bali, 16 April 2013, 409. 